\title{
PENERAPAN POLA NABR DAN TANGHIM DALAM MAHARAH AL KALAM MAHASISWA INDONESIA
}

\author{
Abdul Wahab Rosyidi
}

aw_rosyidi@yahoo.co.id

Jurusan Pendidikan Bahasa Arab Fakultas Ilmu Tarbiyah dan Keguruan

Universitas Islam Negeri Maulana Malik Ibrahim Malang

Jl. Gajayana No 50 Malang

\begin{abstract}
The study aims to reveal and explain the nabr and tanghim pattern of students' Arabic conversation of Arabic Education Department, and to reveal the possibility of meaning change in the nabr and tanghim pattern which is mispronounced. The study is a kind of phenomenological study with a qualitative approach. Data and data sources of this research is three-semester students' Arabic conversation of Arabic Education Department of UIN Maliki with data collection through the documentation, interview, observation, and Participation. While the data analysis technique includes comparison, segmentation, and interpretation step.The Result; that the application of nabr and tanghim patternof students' Arabic conversation of Arabic Education Department is still many difficulties. From the conducted conversations, many idioms spoken are far from the Arabic nabr and tanghim pattern. Nabr and tanghim patterns are often mispronounced is a common phrase used in conversation though different themes, such as; wa'alaikumsalam, afwan, syukron, ahlanbiik, kaifa, madza ... While the misapplication of nabr and tanghim patterns that can lead to changes in the meaning is on the greeting wa'alaikumsalam and should be wa'alaikumussalam, which means specifically into common sense..
\end{abstract}

Keywords: Nabr and tanghim Pattern, Student Conversation

\section{PENDAHULUAN}

Salah satu unsur suprasegmental yang memiliki pengaruh dalam pembeda arti adalah tekanan (Nabr) dan Intonasi (Tanghim). Tekanan atau nabr adalah aktivitas seluruh organ bunyi (speech organs) pada saat yang bersamaan. Biasanya ketika seseorang bertutur cenderung memberikan tekanan pada bagian tertentu dari kosakata yang diucapkan, tujuannya untuk memperjelas bagian-bagian itu ditelinga pendengar. Tekanan ini memungkinkan terjadi secara seporadis, mungkin juga terpola, mungkin pula bersifat distingtif, dapat membedakan makna, dan mungkin juga tidak distingtif , Abdul Chaer ( 2003, h. 121).

Begitu juga apabila kita menuturkan kalimat-kalimat, maka ada nada suara yang berubah-ubah menurut tinggi rendahnya yang disebut dengan intonasi (Tanghim). Ada intonasi khusus untuk kalimat deklaratif dan kalimat interogatif dalam banyak bahasa. Intonasi juga dapat disebabkan oleh unsurunsur lain yang tidak berhubungan dengan jenis kalimat yang membawahi, seperti halnya dengan intonasi yang menunjukkan rasa sedih, gembira, heran, dan lain sebagainya.

Seseorang akan dianggap benar dalam bertutur, jika dapat menjaga secara cermat dan akurat peletakan tekanan dan intonasinya. Dalam berbagai kesempatan kita sering mendengarkan para pebelajar bahasa Arab saat bertutur dengan bahasa yang dipelajari "utamanya pada maharah al kalam", biasanya mereka cenderung meletakkan tekanan dalam kata secara merata, dan 
intonasi kalimat pada akhir tuturan, hal ini tak pelak membuat telingga orang Arab atau orang Indonesia yang sudah fasikh berbahasa Arab merasa asing mendengar penuturan dengan tekanan dan intonasi yang tidak dikenali, bahkan tak jarang hal tersebut menganggu akurasi pemahaman dan makna. Dalam bahasa Arab ada sejumlah kata dan kalimat yang memiliki makna berbeda apabila diberi tekanan dan intonasi yang berbeda, Chotibul Umam (1980, h. 17). Oleh sebab itu perlu dilakukan kajian mendalam terkait dengan bagaimana penuturan bahasa Arab para mahasiswa jurusan pendidikan bahasa Arab dalam percakapannya, karena mereka adalah calon guru bahasa Arab yang akan mengajarkan bahasa tersebut pada peserta didik, tentunya mereka harus menjadi model dalam percakapan.

Dalam kajian fonologi bunyi dapat dibedakan menjadi dua yaitu; bunyi segmental dan suprasegmental. Dan salah satu unsur suprasegmental yang memiliki pengaruh dalam pembedaan arti ujaran adalah tekanan (Nabr). Tekanan atau dalam bahasa Inggris "Stress" merupakan aktivitas seluruh organ bunyi pada saat yang bersamaan. Pada saat pengucapan kata yang diberi tekanan, kita dapat melihat bahwa seluruh organ bunyi beraktifitas secara penuh, dimana semua otot paru-paru mengencang. Demikian pula halnya dengan gerakan dua pita suara, keduanya merengang dan saling mendekat satu sama lain untuk meminimalisir kadar udara yang keluar, sehingga frekwensi getaranpun bertambah, Hilmy Kholil (1997, h. 237). Efek dari proeses tersebut bunyi yang dihasilkan menjadi kuat dan jelas dipendengaran. Situasi ini terjadi pada saat pengucapan bunyi-bunyi bersuara (majhur). Sedangkan dalam bunyibunyi tak bersuara (mahmus), yang terjadi adalah kebalikannya, yakni kedua pita suara saling menjauh-lebih dari pada produksi bunyi tak bersuara yang tidak di tekan, karena kadar udara yang keluar relatif besar.

Bahasa Arab, sampai saat ini belum memiliki pedoman khusus untuk menelusuri posisi tekanan dalam bahasa Arab. Namun demikian para pakar linguistik Arab modern telah banyak memberikan gambaran umum tentang tekanan dalam bahasa Arab, misalnya Ibrahim Anis (1979, h. 85) mengatakan; bahwa untuk mengetahui posisi tekanan dalam bahasa Arab;
Pertama, dapat melihat suku kata terakhirnya. Jika suku kata tersebut berposisi sebagai suku kata yang keempat atau kelima, dalam kata bahasa Arab yang tersusun dari empat atau lima jenis kata, maka suku kata yang terakhir inilah yang memperoleh tekanan (nabr). Akan tetapi perlu diingat, hal ini hanya berlaku pada saat berhenti (waqof). Jadi tekanan pada suku kata terakhir hanya terjadi pada saat waqof, dan suku kata tersebut berada pada jenis kata yang keempat atau kelima. Atau dengan rumusan berikut:

konsonan + vocal panjang + konsonan, atau konsonan + vokal panjang + dua konsonan.

Sebagai contoh kata berikut; ketika إياك " pada kalimat / نستعين / pada pada kata /

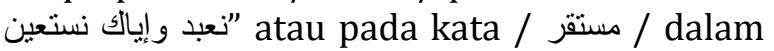
ayat " kita menemukan tekanan (nabr) pada maqtho' / قرّ / ل عين / dan /.

Kedua, apabila sebuah kata tidak termasuk dalam jenis dua suku kata tersebut, maka tekanan (nabr) jatuh pada suku kata akhir. Pada umumnya posisi tekanan (nabr) dalam beberapa kosakata Arab memang terletak pada suku kata sebelum akhir, seperti; " atau " atau " atau " atau " ata " ata " “ يكتب "

Ketiga, dalam kata kerja bentuk lampau ( fi'il madhi tsulasi) yang terdiri dari tiga huruf seperti " كتب ,صعب ,حفر , tekanan terletak pada suku kata ketiga dihitung dari belakang, yakni pada maqtho' / S /, /, dan / / / / إجتمع Demikian juga pada kata kerja " إنكسر / dan " atau pada kata yang berbentuk masdar " فرح ح"

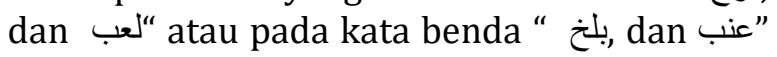
kita dapati tekanan berada pada suku kata yang ketiga duhitung dari akhir kata.

Sedangkan yang keempat meskipun sangat jarang, yakni ketika sebuah kata seperti " dalam kasus ini, tekanan (nabr) terletak pada suku kata yang keempat dihitung dari akhir kata, yaitu pada " $\tau, \varepsilon$, "Tekanan dalam bahasa Arab memiliki empat posisi, yang populer adalah suku kata sebelum kata terakhir, ringkasnya sebagai berikut;

a) Untuk mengetahui posisi tekanan pada kosakata Arab, pertama-tama dengan melihat suku kata terakhir. Jika sebuah kata tersusun dari empat atau lima suku kata, maka tekanan berada pada suku kata terakhir. 
b) Jika tersusun dari dua atau tiga suku kata, maka dengan melihat suku kata sebelum suku kata terakhir, disitulah letak tekanan bunyinya.

c) Jika hanya tersusun dari satu suku kata, maka tekanan terletak pada huruf pertama.

d) Tekanan tidak akan pernah berada pada suku kata keempat dihitung dari akhir kata kecuali satu kasus, yakni ketiga suku kata sebelum terakhir itu sejenis.

Demikian beberapa posisi tekanan dalam bahasa Arab seperti dirumuskan oleh para pakar qiro'at di Kairo Mesir, Ibrahim Anis (1979, h. 3). Dan lihat pula pada Ali Al Khouly dalam Asaalibu Tadris al Lughoh al Arabiyah (1982, h. 48-49). Hal ini dapat dipahami bahwa fenomena kebahasaan di atas tidaklah bertumpu pada perasaan (sense) ketika bertutur, namun lebih merupakan kebiasaan yang diwariskan secara turun temurun. Dan tidak semua perbedaan peletakan tekanan dalam kosakata bahasa Arab selalu mempengaruhi makna maupun penggunaannya dalam kalimat.

Oleh karenanya penambahan tekanan pada sebuah kata dalam kalimat tidak akan lepas dari penambahan tekanan pada suku kata tertentu dalam kata itu. Dalam kata " أخوك ", kita tahu dari kaidah sebelumnya bahwa suku kata yang diberi tekanan adalah " خو ", dan ketika kata " أخوك ", diberikan tekanan sesungguhnya adalah pemberian tekanan pada suku kata " خو ", agar terdengar lebih jelas ditelinga.

Seseorang ketika bertutur dengan bahasanya tidak hanya mengikuti sebuah irama tertentu dalam pengucapan beragam bunyinya. Sebuah bunyi yang menyusun sebuah suku kata kadang memiliki irama yang berlainan, demikian pula dengan halnya bunyi-bunyi yang menyusun kata. Intonasi dihasilkan oleh getaran pita suara akibat arus udara yang disebabkan oleh adanya perbedaan tekanan udara di dalam paru-paru dan dalam ruangan supraglotal, Sugiyono (2003, h. 27). Terdapat beberapa bahasa yang sangat bertumpu perbedaan irama bunyi dan menetapkannya sebagai aspek yang vital, dan dalam hal ini makna kata takjarang berbeda hanya disebabkan perbedaan irama pengucapannya. Sebagai contoh yang paling populer adalah dalam bahasa China, dalam bahasa ini sebuah kata kadang memiliki beragam makna, tergantung pada intonasi pengucapannya. Dalam bahasa China kata “ fan " dengan irama (tone) yang berbeda akan memiliki enam kemungkinan makna yang satu dengan yang lain tidak terkait, yaitu; tidur, terbakar, berani, wajib, membagi, dan kelelahan, J.W.M. Verhaar (2001, h. 91).

Rangkaian intonasi yang selalu kita dengar itu mengikuti pola tertentu yang berbeda-beda antara satu bahasa dengan bahasa lainnya. Memahami pola intonasi yang ada pada suatu bahasa merupakan hal yang sangat penting, Chotibul Umam (1980, h. 16). Apabila intonasi tidak dipahami bahasa yang terucap akan kehilangan corak khas dan karakteristik pengucapannya, Kamal Muhammad Basyar (1980, h. 163).

Kajian serupa terhadap bunyi suprasegmental atau dalam istilah John. R. Frithian "prosodi", dalam bidang ini pernah dikaji oleh Laksman (1996) Ebing (1994) dan Ode (1994), serta Ramijsen (2002), mereka menekankan akan pentingnya penerapan nabr dan tanghim pada kata dan kalimat. Dan yang paling terkini penelitian yang dilakukan oleh Sonia Rabih (2013) akan pentingnya penerapan pengucapan bunyi yang benar dalam bertutur. Bagaimana penerapan pola nabr dan tanghim, dan apa pola nabr dan tanghim yang sering mengalami kesalahan, serta apakah kesalahan penerapan tersebut dalam Maharah al Kalam mahasiswa jurusan pendidikan bahasa Arab dapat menimbulkan perubahan makna?

Adapun tujuan yang hendak dicapai dalam penelitian ini adalah; ingin mengungkap pola Nabr dan Tanghim, dan ingin menjelaskan secara detail pola $\mathrm{Nabr}$ dan Tanghim, serta ingin mengungkapkan kemungkinan terjadinya perubahan makna pada pola Nabr dan Tanghim yang salah dalam Maharah al Kalam mahasiswa jurusan pendidikan bahasa Arab Fakultas Ilmu Tarbiyah dan Pendidikan Universitas Islam Negeri Maulana Malik Ibrahim Malang.

\section{METODE PENELITIAN Lingkup Penelitian}

Penelitian ini tidak ingin mengungkap seluruh ujaran atau ungkapan yang digunakan mahasiswa dalam maharah al kalam, akan tetapi hanya mengungkap pola-pola ujaran atau ungkapan yang mengandung tekanan (nabr) dan intonasi (tanghim), pola tersebut 
terdapat dalam kata atau rangkaian kata, dan ungkapan yang mengalami pergeseran tidak sesuai dengan pola yang telah ditentukan oleh ahli linguistik Arab. Ujuran yang dimaksud adalah, percakapan bahasa Arab yang digunakan oleh mahasiswa jurusan pendidikan bahasa Arab semester III tahun akademik 2015/20116.

\section{Sumber Data}

Adapun sumber data dalam penelitian ini dibagi dalam dua kelompok. Pertama; data primer, yaitu sumber utama yang menjadi objek kajian ini. Data ini tidak lain adalah ujaran/ungkapan mahasiswa jurusan pendidikan bahasa Arab semester III tahun akademik 2015/2016 dalam maharah kalam dengan mengambil sampel 4 tema percakapan yang dilakukan oleh 9 mahasiswa yang memiliki latar belakang bahasa Ibu seperti Jawa, Madura, lombok. Kedua; data skunder, yaitu percakapan nathiq asli yang berbentuk rekaman, dan buku-buku yang memiliki keterkaitan dan mendukung terhadap objek penelitian. Buku-buku tersebut seperti; ilmu Ashwat, Linguistik Umum, ilmu Tajwid, Fonologi Bahasa Indonesia, dan berbagai buku yang memiliki keterkaiatan dengan objek.

\section{Teknik Pengumpulan data}

Teknik pengumpulan data yang digunakan dalam penelitian ini melalui beberapa tahap; pertama, dokumentasi. Dalam tahap ini, data atau informasi yang berkaiatan dengan objek penelitian dikumpulkan seperti latar belakang atau pengalaman partisipan. Kedua, Interview. Yaitu, melakukan wawancara dengan pengampu mata kuliah maharah kalam terkait dengan kemampuan mahasiswa dalam percakapan dan penerapan pola nabr dan tanghim. Ketiga, observasi dan partisipasi. Yakni peneliti langsung turun lapangan untuk mengamati prilaku dan aktivitas individuindividu di lokasi penelitian, dalam pengamatan ini peneliti merekam dan juga mencatat ujaran atau ungkapan mahasiswa dalam maharah al kalam. Suharsimi Arikunto (2010, h. 264).

\section{Teknik Analisis Data.}

Data yang sudah dikumpulkan sebagaimana tersebut di atas dianalisa dengan beberapa tahapan; a) Komparasi, dengan teknik ini data dibandingkan dengan data lain, sehingga ditemukan gambaran yang jelas, Anton Baker, \& Charis (tt, h. 50-51), dimana data hasil rekaman tuturan 9 Mahasiswa Jurusan Pendidikan bahasa Arab FITK UIN Maliki Malang yang memiliki latar belakang bahasa Ibu yang berbeda sebagaimana tersebut di atas dibandingkan dengan tuturan native dalam bentuk MP3 materi maharah kalam buku Arabiyah Baina Yadaik.

b) Segmentasi, hal ini dilakukan untuk menandai batas-batas satuan analisis yang telah ditentukan, Sugiyono (2003, h. 59) yaitu menandai satuan tekanan dalam suku kata, kata, dan gabungan kata dalam kalimat tuturan mahasiswa, sehingga akan terlihat jelas pola penggunaan nabr dan tanghim.

Interpretasi, yaitu mengungkap polapola nabr dan tanghim yang digunakan mahasiswa bertutur dalam maharah al kalam. Dalam hal ini kesalahan-kesalahan yang berupa bunyi supra-segmental yang dimungkinkan dapat merubah makna. Interpretasi dilakukan bukan merupakan tindakan mana suka untuk mendapatkan kepuasan berfikir belaka, akan tetapi sebuah pemahaman yang dibangun atas dasar pencermatan secara objektif dalam rangka mencapai pemahaman yang paling akurat dan orisinil, Anton Baker, \& Charis (tt, h. 24-31).

\section{DISKUSI DAN TEMUAN}

Data dalam penelitian ini berbentuk tuturan percakapan yang terekam dalam bentuk MP3, karena obyek penelitiannya bahasa lisan bukan bahasa tulis. Untuk memudahkan dalam analisa data, maka peneliti mentranskip ke dalam bahasa tulis. Data yang diperoleh dalam bentuk percakapan mahasiswa jurusan pendidikan bahasa Arab Fakultas Ilmu Tarbiyah dan Keguruan Universitas Islam Negeri Maulana Malik Ibrahim Malang dengan tema-tema yang telah mereka pilih sendiri seperti; ar Rihlah, fil Math'am, at Ta'allum, dan Kitabatul Wadhifah. data yang akan dianalisis dalam penelitian ini adalah tema ar Rihlah dengan paparan sebagai berikut;

فاطمة




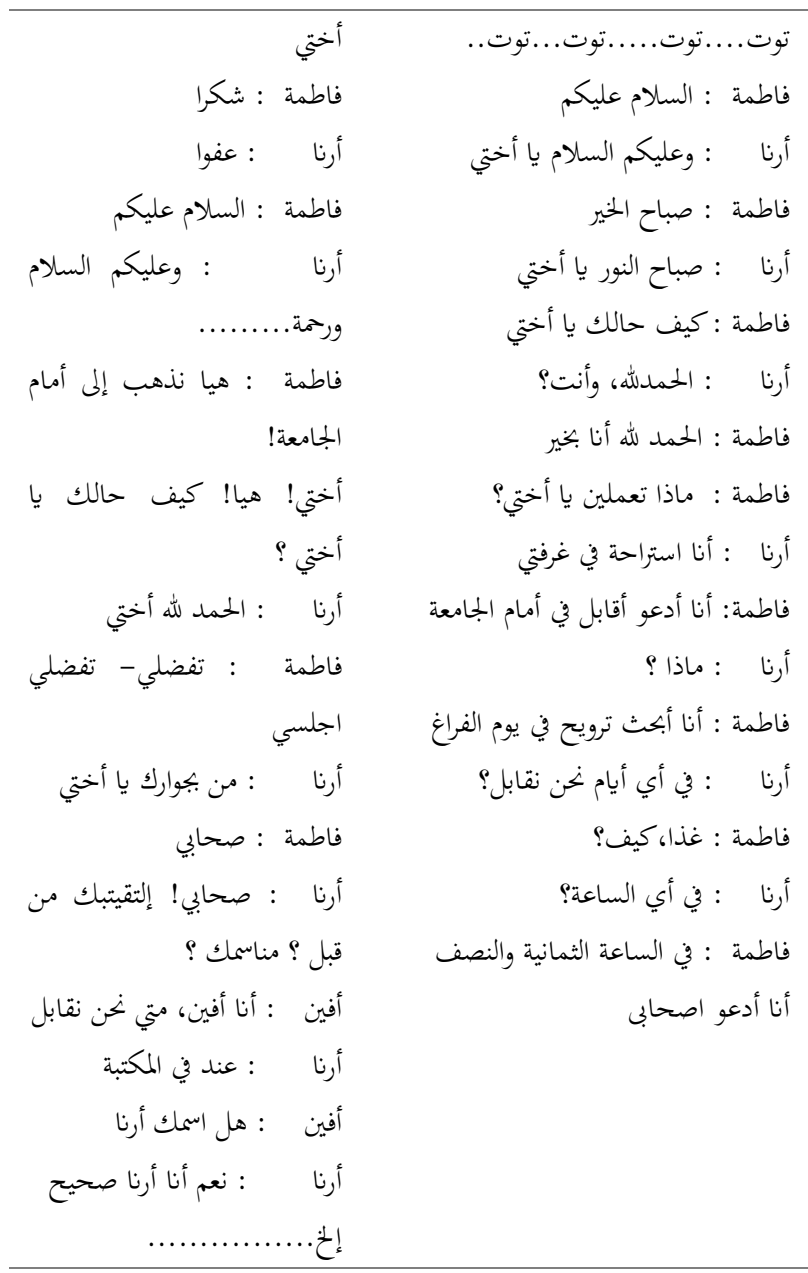

\section{Penerapan Pola Nabr dan Tanghim dalam Percakapan Bahasa Arab Mahasiswa.}

Pada dasarnya mahasiswa jurusan pendidikan bahasa Arab fakultas ilmu tarbiyah dan pendidikan sudah memiliki bekal pengetahuan minimal dalam maharah al kalam, dan juga sudah mendapatkan contohcontoh pengucapan dan pengungkapan yang baik dan benar dari dosen pengampu mata kuliah, serta sudah mengikuti program intensif bahasa Arab selama 2 semester. Bekal tersebut semestinya sudah dapat dijadikan sebagai modal untuk mengembangkan maharah al kalamnya pada jenjang berikutnya, namun pada kenyataan mereka masih banyak mengalami hambatanhambatan untuk melakukan percakapan dengan baik dan benar sesuai dengan kaidah nabr dan tanghim yang telah dipolakan oleh para linguist Arab seperti; Ali Al Khouly dan Ibrahim Anis.

Dalam melakukan percakapan sesama teman atau dengan dosen, dengan native speaker sering sekali terdengan ungkapan yang kadang-kandang membuat lawan bicara binging dengan isi pesan yang disampaikan. Faktor yang paling dominan dalam peristiwa ini adalah; penutur sering mengikutkan pola intonasi bahasa Ibu kedalam bahasa yang sedang dipelajari. Hal ini dilakukan dalam alam bawah sadar scara otomatis karena kebiasan yang sudah melekat. Adapun penerapan pola nabr dan tanghim dalam percakapan bahasa arab mahasiswa jurusan pendidikan bahasa Arab tergambar sebagai berikut;

\begin{tabular}{|c|c|}
\hline Segmentasi Ujaran & Uraian Penerapan Pola \\
\hline & $\begin{array}{lrr}\text { Nabr dan } & \text { TanghimDalam } \\
\text { maharah } & \text { al } & \text { kalam } \\
\text { Mahasiswa } & & \\
\end{array}$ \\
\hline 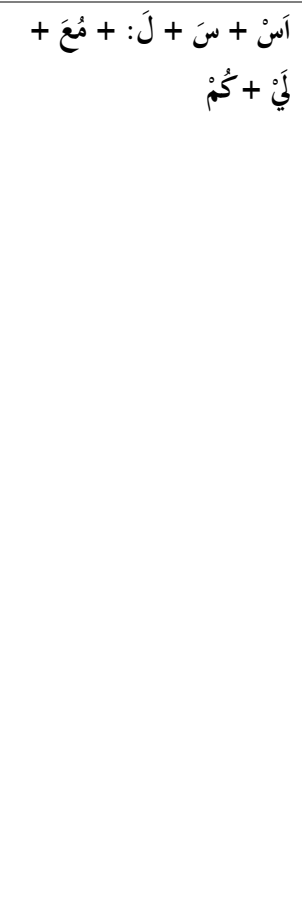 & $\begin{array}{l}\text { Ungkapan ini terdiri dari dua } \\
\text { kata, dan kata pertama terdiri } \\
\text { dari empat moqtho' } \\
\text { sedangkan kata kedua terdiri } \\
\text { dari tiga maqtho'. Pengucapan } \\
\text { kalimat tersebut terdengar } \\
\text { datar, tidak ada pembedaan } \\
\text { pemberian tekanan pada } \\
\text { masing-masing maqtho'. } \\
\text { Seharusnya pengucapannya } \\
\text { dengan memberikan nabr } \\
\text { pada maqtho' yang ketiga, } \\
\text { karena kata tersebut terdiri } \\
\text { dari empat maqtho sedangkan } \\
\text { maqtho' ketiga panjang } \\
\text { sebagimana kaidah yang } \\
\text { berlaku. Begitu juga dengan } \\
\text { kata yang kedua seharusnya } \\
\text { memberikan nabr pada } \\
\text { maqtho' yang pertama karena } \\
\text { terdiri dari tiga maqtho' yang } \\
\text { semuanya pendek. Dan untuk } \\
\text { intonasi (tanghim) kalimat ini } \\
\text { mendatar karena termasuk } \\
\text { kalam khobar }\end{array}$ \\
\hline 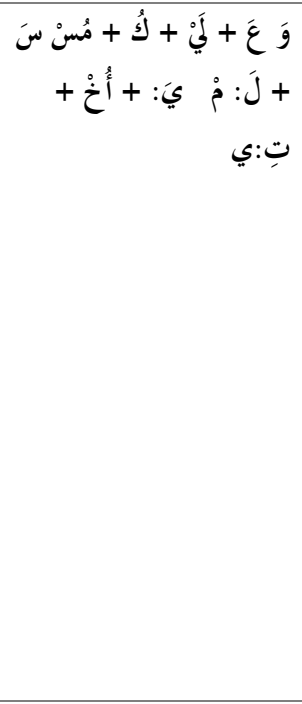 & $\begin{array}{l}\text { Dalam ungkapan ini terdapat } \\
\text { empat kata; kata pertama satu } \\
\text { maqtho' mendapat tekanan, } \\
\text { sedangkan kata yang kedua } \\
\text { mengalami perpindahan } \\
\text { tekanan disebabkan karena } \\
\text { maqtho yang terakhir } \\
\text { merupakan maqtho terbuka } \\
\text { yang tidak boleh disukun, } \\
\text { sehingga harus meletakkan } \\
\text { nabr pada maqtho terbuka } \\
\text { tersebut untuk menyelamatk } \\
\text { makna yang terkadung. } \\
\text { Sedangkan untuk kata yang } \\
\text { ketiga jelas nabr terletak pada } \\
\text { akhir maqtho, karena terdiri } \\
\text { dari dua maqtho sedangkan } \\
\text { maqtho terakhir dari jenis } \\
\text { maqtho' panjang. }\end{array}$ \\
\hline
\end{tabular}




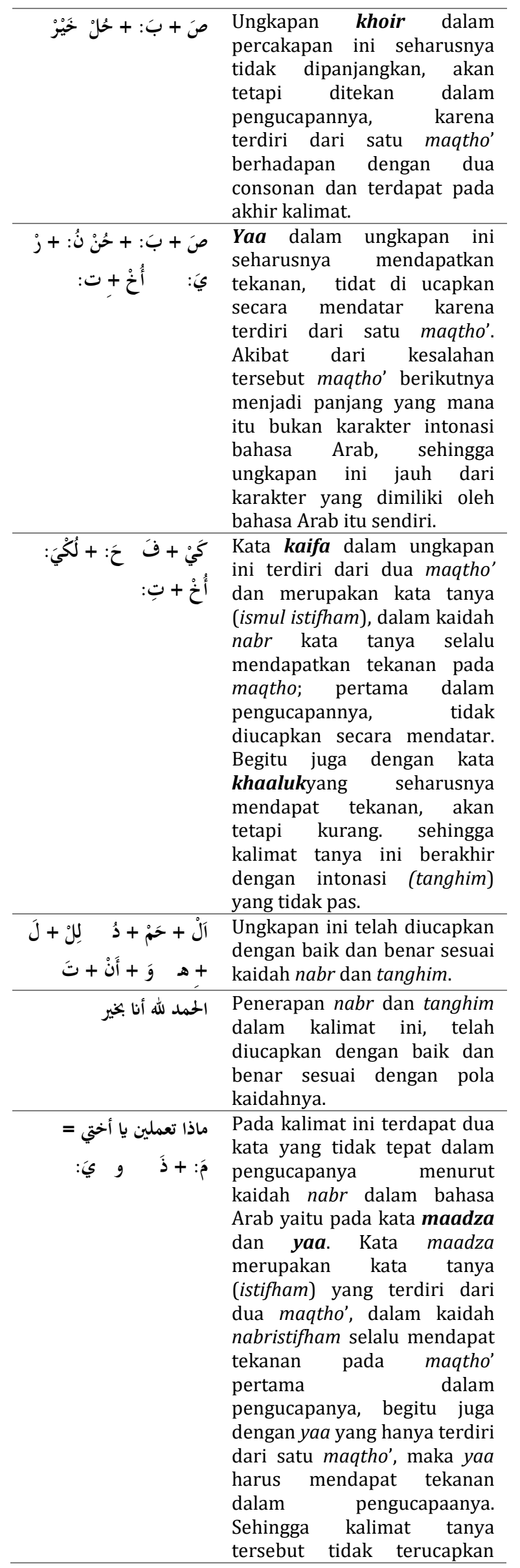

\begin{tabular}{|c|c|}
\hline & secara mendatar. \\
\hline أنا استراحة في غرفتي & $\begin{array}{l}\text { - Ungkapan kurang memenuhi } \\
\text { syarat secara kaidah tata } \\
\text { bahasa Arab. }\end{array}$ \\
\hline 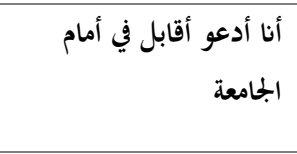 & 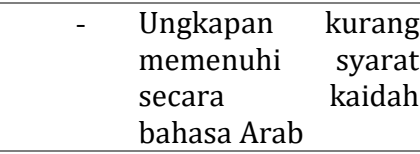 \\
\hline ماذا & $\begin{array}{l}\text { Kata ini sebagaimana tersebut } \\
\text { di atas kurang mendapatkan } \\
\text { tekanan pada penggalan kata } \\
\text { yang pertama. Sehingga } \\
\text { terucap seperti intonasi } \\
\text { bahasa Indonesia. }\end{array}$ \\
\hline 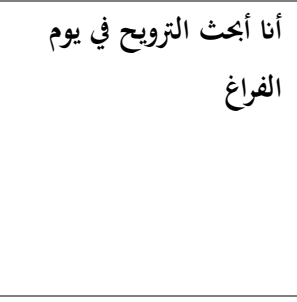 & $\begin{array}{l}\text { Penerapan nabr dan tanghim } \\
\text { jauh dari kaidah yang telah } \\
\text { ditentukan dalam bahasa } \\
\text { Arab, sehingga ungkapan ini } \\
\text { kehilangan karakter dan ciri } \\
\text { khasnya, dan akan terasa } \\
\text { asing bila pemilik bahasa } \\
\text { mendengarkan ungkapan ini. }\end{array}$ \\
\hline في أي أيام نحن نقابل & $\begin{array}{l}\text { Pengucapan ini telah } \\
\text { memenuhi kaidah nabr dan } \\
\text { tanghim yang telah } \\
\text { ditentukan, sebagai kalimat } \\
\text { tanya yang memiliki intonasi } \\
\text { suara naik diakhir kalimat. }\end{array}$ \\
\hline غذا، كيف & $\begin{array}{l}\text { Ungkapan kurang memenuhi } \\
\text { syarat secara kaidah tata } \\
\text { bahasa Arab }\end{array}$ \\
\hline في أي الساعة & $\begin{array}{lrr}\text { Pengucapan ini } & \text { telah } \\
\text { memenuhi kaidah } & \text { nabr dan } \\
\text { tanghim yang } & \text { telah } \\
\text { ditentukan } & & \end{array}$ \\
\hline في الساعة الثمانية والنصف & $\begin{array}{l}\text { Ungkapan kurang memenuhi } \\
\text { syarat secara kaidah tata } \\
\text { bahasa Arab }\end{array}$ \\
\hline أنا أدعوا صحابى & $\begin{array}{l}\text { Ungkapan kurang memenuhi } \\
\text { syarat secara kaidah tata } \\
\text { bahasa Arab }\end{array}$ \\
\hline نعم ما في المشكلة يا أختي & $\begin{array}{l}\text { Pengungkapan dan } \\
\text { pengucapan sudah mendekati } \\
\text { kaidah }\end{array}$ \\
\hline شُُكْ + رَنْ & $\begin{array}{l}\text { Ungkapan ini (syukron) } \\
\text { terdiri dari dua maqtho' yang } \\
\text { sama-sama pendeknya, } \\
\text { sehingga tekanan jatuh pada } \\
\text { maqtho' yang pertama, tidak } \\
\text { perlu memberi tekanan lagi } \\
\text { pada maqtho' yang kedua, } \\
\text { begitu juga dengan intonasi } \\
\text { yang seharusnya diucapkan } \\
\text { mendatar tidak memanjang. }\end{array}$ \\
\hline عَفْ + وَنْ & $\begin{array}{l}\text { Hal yang sama juga terjadi } \\
\text { pada kata affan, dimana } \\
\text { ungkapan ini terdiri dari dua } \\
\text { maqtho' yang sama-sama } \\
\text { pendeknya, sehingga tekanan } \\
\text { jatuh pada maqtho' yang } \\
\text { pertama. }\end{array}$ \\
\hline السلام عليكم & $\begin{array}{l}\text { Sebagaimana ungkapan salam } \\
\text { di atas tidak ada perubahan } \\
\text { dalam pengucapan salam } \\
\text { penutup. }\end{array}$ \\
\hline
\end{tabular}




\section{Sebagaimana ungkapan salam di atas tidak ada perubahan dalam pengucapan salam penutup.}

Dalam tabel data tersebut di atas terdapat 32 ungkapan baik dalam bentuk kata atau kalimat dengan rincian; 27 kalimat sempurna, 5 kalimat belum memenuhi syarat tatanan kalimat sempuna (jumlah mufiidah), dari 32 ungkapan itu terdiri atas; 113 kata. Dalam data tesebut ada beberapa ungkapan yang sudah terekam, akan tetapi tidak ditranskipkan dalam bahasa tulis. Hal tersebut disebabkan adanya pengulangan kata dalam ungkapan tersebut, sehingga peneliti menganggap cukup untuk mengsegmentasi data yang mewakilinya sebagaimana dalam tabel segmentasi data di atas.

Dari 32 ungkapan dalam percakapan dengan tema "ar Rihlah" tersebut, terdapat 4 ungkapan yang dalam pengucapannya telah memenuhi penerapan pola kaidah nabr dan tanghim, dan seperti apa yang diucapakan oleh native dalam contoh rekaman MP3 buku Al Arabiyah Lin Nasyiin. Dan terdapat 5 ungkapan yang susunan kalimatnya tidak sesuai dengan aturan nahwu, dan perubahan kata dalam kalimat tidak sesuai dengan aturan shorof. Sedangkan kata atau kalimat yang tidak sesuai pengucapannya dengan kaidah nabr dan tanghim terdapat 12 ungkapan, hal itu terulang pada percakapan dalam tematema lain. Oleh karenanya perlu diperhatian oleh para pengampu mata kuliah keterampilan berbicara. Kata-kata tersebut sering menyertai dalam setiap kali percakan pebelajar seperti ungkapan; syukrom, afwan, khoiir, kaifa, maadza.

Pola Nabr Dan Tanghim Yang Sering Mengalami Kesalahan Dalam Percakapan Bahasa Arab Mahasiswa

\begin{tabular}{|c|c|}
\hline $\begin{array}{l}\text { Ungkapan Yang } \\
\text { Sering Mengalami } \\
\text { Kesalahan dalam } \\
\text { penerapan Nabr } \\
\text { dan Tanghim }\end{array}$ & $\begin{array}{l}\text { Perubahan } \quad \text { Nabr dan } \\
\text { Tahghim }\end{array}$ \\
\hline كَيْفَ & $\begin{array}{l}\text { Ungkapan kaifa dalam dialog } \\
\text { ini menentukan intonasi dalam } \\
\text { kalimat tanya. Kata kaifa yang } \\
\text { sering diucapkan secara } \\
\text { mendatar menjadikan intonasi } \\
\text { kalimat tanya pada kata } \\
\text { akhirnya menjadi panjang } \\
\text { melembut }\end{array}$ \\
\hline
\end{tabular}

\begin{tabular}{|c|c|}
\hline شُكُرًا & $\begin{array}{l}\text { Perubahan ungkapan ini sering } \\
\text { diucapkan dengan pola } \\
\text { intonasi bahasa Indonesia atau } \\
\text { Jawa, sehingga ungkapan ini } \\
\text { kehilangan ciri dan } \\
\text { karakternya. Yang seharusnya } \\
\text { diucapkan dengan memberikan } \\
\text { tekanan pada maqtho' yang } \\
\text { pertama, karena ungkapan ini } \\
\text { terdiri dari dua maqtho' yang } \\
\text { pendek. }\end{array}$ \\
\hline عَفْوًا & $\begin{array}{l}\text { Perubahan yang sama terjadi } \\
\text { dalam ungkapan affan, } \\
\text { sebagaimana ungkapan } \\
\text { syukron di atas }\end{array}$ \\
\hline مَاذَا & $\begin{array}{l}\text { Kata maadza merupakan kata } \\
\text { tanya, dan ketika kata ini tidak } \\
\text { ditekan pada maqtho' yang } \\
\text { pertama maka akan terjadi } \\
\text { pemanjangan bunyi pada akhir } \\
\text { kalimat tanya dan kehilangan } \\
\text { intonasi yang sebenarnya }\end{array}$ \\
\hline إلى للقاء & $\begin{array}{l}\text { Ungkapan ini sebenarnya } \\
\text { ditekan pada maqtho' terakhir, } \\
\text { bukan dipanjangkan. }\end{array}$ \\
\hline أَهْلابِكْ & $\begin{array}{l}\text { Ungkapan ini salah dalam } \\
\text { penerapan tekanan, maqtho } \\
\text { yang seharusnya ditekan tidak } \\
\text { dipanjangkan. }\end{array}$ \\
\hline يا أخت صباح الحخير. & $\begin{array}{l}\text { Kesalahn terjadi pada kata } \\
\text { khoir, lagi-lagi tidak ditekan } \\
\text { dan diucapkan panjang, } \\
\text { sehingga intonasinya salah. }\end{array}$ \\
\hline
\end{tabular}

Dalam tabel tersebut di atas ada tujuh ungkapan yang dalam penerapan pola nabr dan tanghim kurang tepat. Kurang tepatnya terletak pada peletakan tekanan pada tataran kata dan intonasi pada akhir kalimat. Kesalahan tersebut tidak berpotensi menimbulkan perubahan makna yang dikandung, akan tetapi memberikan dampak pada hilangnya ciri dan karakter bahasa Arab. Tujuh kata tersebut diucapkan dengan pola nabr dan tanghim bahasa Indonesia atau Jawa sehingga pengucapannya cenderung lemah dan mendatar, serta lembek tidak terlihat tekanan pada sebuah kata satu dengan kata lain.

\section{Kesalahan Penerapan Pola Nabr Dan Tanghim Dalam Percakapan Bahasa Arab Mahasiswa}

Salah satu unsur suprasegmental yang memiliki pengaruh dalam pembeda arti adalah tekanan (Nabr) dan Intonasi (Tanghim). Dalam bahasa Arab ada sejumlah kata dan kalimat yang memiliki makna berbeda apabila diberi tekanan dan intonasi 
yang berbeda. Secara umum keselahan penerapan Nabr dan Tanghim pada kata atau kalimat belum sepenuhnya dapat merubah makna. Adapun kesalahan penerapan polanabr dan tanghim dalam maharah al kalam mahasiswa jurusan pendidikan bahasa arab yang dapat menimbulkan perubahan makna adalah sebagai berikut;

\begin{tabular}{|c|c|}
\hline $\begin{array}{l}\text { Kesalahan } \mathrm{Nabr} \\
\text { dan Tanghim }\end{array}$ & Perubahan Makna \\
\hline وَعَلَيْكُُمُ السَّلَاَمْ & $\begin{array}{l}\text { Dalam ungkapan ini terdapat tiga } \\
\text { kata; kata pertama satu maqtho } \\
\text { mendapat tekanan, sedangkan } \\
\text { kata yang kedua mengalami } \\
\text { perpindahan tekanan disebabkan } \\
\text { karena maqtho yang terakhir } \\
\text { merupakan maqtho terbuka yang } \\
\text { tidak boleh disukun, sehingga } \\
\text { harus meletakkan nabr pada } \\
\text { maqtho terbuka tersebut untuk } \\
\text { menyelamatk makna yang } \\
\text { terkadung. Sedangkan untuk kata } \\
\text { yang ketiga jelas nabr terletak } \\
\text { pada akhir maqtho, karena terdiri } \\
\text { dari dua maqtho sedangkan } \\
\text { maqtho terakhir dari jenis } \\
\text { maqtho' panjang. Perubahan } \\
\text { makna dari ungkapan ini karena } \\
\text { kesalahan dalam penempatan } \\
\text { nabr sangat berarti, dari kata } \\
\text { yang memiliki makna yang } \\
\text { khusus menjadi makna yang luas } \\
\text { karena kehilangan partikel al. } \\
\text { Makna salam dari Allah berubah } \\
\text { menjadi salam dari siapapun. }\end{array}$ \\
\hline كَيْفَ & $\begin{array}{l}\text { Kata ini tidak mengalami } \\
\text { perubahan makna, akan tetapi } \\
\text { kehilangan ciri dan karakter } \\
\text { bahasa pada kata tersebut }\end{array}$ \\
\hline شُكُرًا & $\begin{array}{l}\text { Kata ini tidak mengalami } \\
\text { perubahan makna, akan tetapi } \\
\text { kehilangan ciri dan karakter dari } \\
\text { bahasa tersebut }\end{array}$ \\
\hline عَفْوًا & $\begin{array}{l}\text { Kata ini tidak mengalami } \\
\text { perubahan makna, akan tetapi } \\
\text { kehilangan ciri dan karakter dari } \\
\text { bahasa tersebut }\end{array}$ \\
\hline مَاذًا & $\begin{array}{l}\text { Kata ini tidak mengalami } \\
\text { perubahan makna, akan tetapi } \\
\text { kehilangan ciri dan karakter dari } \\
\text { bahasa tersebut }\end{array}$ \\
\hline إلى للقاء & $\begin{array}{l}\text { Kata ini tidak mengalami } \\
\text { perubahan makna, akan tetapi } \\
\text { kehilangan ciri dan karakter dari } \\
\text { bahasa tersebut }\end{array}$ \\
\hline أَهْلابِكْ & $\begin{array}{l}\text { Kata ini tidak mengalami } \\
\text { perubahan makna, akan tetapi } \\
\text { kehilangan ciri dan karakter dari } \\
\text { bahasa tersebut, sehingga terasa } \\
\text { aneh apabila didengan oleh } \\
\text { pemilik bahasa. }\end{array}$ \\
\hline & $\begin{array}{l}\text { Kata ini tidak mengalami } \\
\text { perubahan makna, akan tetapi }\end{array}$ \\
\hline
\end{tabular}

kehilangan ciri dan karakter dari bahasa tersebut

Dalam ungkapan nomor satu terdapat tiga kata, kata pertama satu maqtho' mendapat tekanan, sedangkan kata yang kedua mengalami perpindahan tekanan disebabkan karena maqtho yang terakhir merupakan maqtho terbuka yang tidak boleh disukun, sehingga harus meletakkan nabr pada maqtho terbuka tersebut untuk menyelamatkan makna yang terkandung. Atau dengan cara menjadikan kata kedua menjadi dua maqtho dan kata ketiga menjadi tiga maqtho'. Sedangkan untuk kata yang ketiga jelas nabr terletak pada akhir maqtho, karena terdiri dari dua maqtho sedangkan maqtho terakhir dari jenis maqtho' panjang. Perubahan makna dari ungkapan ini karena kesalahan dalam penempatan nabr sangat berarti, dari kata yang memiliki makna yang khususn menjadi makna yang luas karena kehilangan partikel al.

Sedangkan untuk ungkapan-ungkapan yang lain yang tidak mengindahkan kaidah nabr dan tanghim yang telah dibuat oleh para linguist Arab, hanya kehilangan ciri dan karakter bahasa tersebut, dan hal tersebut juga akan berdampak pada pendengaran pemilik bahasa yang merasa asing dengan ungkapan tersebut.

\section{SIMPULAN}

Dari pemaparan dan analisa terhadap data dalam penelitian ini, maka dapat disimpulkan beberapa hal terkait dengan penerapan pola nabr dan tanghim dalam percakapan bahasa Arab mahasiswa jurusan pendidikan bahasa Arab adalah sebagai berikut, pertama; dalam menerapan pola $n a b r$ dan tanghim pada percakapan maharah Kalam mahasiswa jurusan pendidikan bahasa Arab masih banyak yang mengalami kesulitan. Dari percakapan yang dilakukan banyak ungkapanungkapan yang diucapkan jauh dari pola nabr dan tanghim bahasa Arab, pengucapan mereka lebih dekat dengan mengunakan nabr dan tanghim bahasa ibu. Kedua; pola nabr dan tanghim yang sering mengalami kesalahan dalam percakapan bahasa Arab mahasiswa jurusan pendidikan bahasa Arab adalah ungkapan-ungkapan yang umum digunakan dalam percakapan meskipun berbeda tema, seperti; wa'alaikum salam, afwan, syukron, 
ahlan biik, kaifa, madza, dan beberapa ungkapan yang juga masih kurang dalam penerapannya.Ketiga; kesalahan penerapan pola nabr dan tanghim dalam percakapan bahasa Arab mahasiswa jurusan pendidikan bahasa Arab yang dapat menimbulkan perubahan makna adalah adalah pada ungkapan salam pembuka yang diucapkan wa'alaikum salam dan seharusnya wa'alaikumus salam, yang seharusnya memiliki arti khusus menjadi arti yang umum.

Oleh karenanya dalam pembelajaran keterampilan berbicara hendaknya memperhatikan aspek bunyi suprasegmental, bunyi ini tidak tersimbolkan, bunyi ini akan terlihat apabila diucapkan, disamping pengucapan bunyi, tatabahasa, pemilihan kata, kelancaran, dan pesan. Sedangkan untuk meminimalisir kesalahan dan kekurangtepatan nabr dan tanghim dalam keterampilan berbicara hendaknya pembelajaran keterampilan tersebut menggunakan pendekatan driil terhadap bunyi suprasegmental. Dan hendaknya dalam pembelajaran keterampilan berbicara bunyi suprasegmental diperhatikan dengan sebaikbaiknya, karena kesalahan dalam penerapannya akan berdampak pada hilangnya ciri dan karateristik bahasa tersebut, bahkan menimbulkan kesalahan arti.

\section{DAFTAR PUSTAKA}

al Khouly, M. Ali. (1982). Asalib Tadris al Lughoh al Arabiyah. Riyadh: al Mamlakah al Arabiyah as Saudiyah.

Anis, Ibrahim. (1979). Al Ashwat al Lugowiyah. al Qhohiroh: Maktabah Anjalu.

Arikunto, Suharsimi. 2010. Prosedur Penelitian-Suatu Pendekatan Praktik. Jakarta: Rineka Cipta.

Baker, Anton, dan Charis Zubair, Achmad. tt. Metodologi Penelitian Filsafat. Yogyakarta: Kanisius.

Chaer, Abdul. (2003). Linguistik Umum. Jakarta: Rineka Cipta

Creswell, John W. (2009). Pendekatan Kualitatif, Kuantitatif, dan Mixed. Yogyakarta: Pustaka Pelajar.

Ibrahim Badry, Kamal. (1988). IlmuLughoh al Mubarnaj-al Ashwat Wan Nidhomu al Shouty Muthobaqot Ala al Lughoh al Arabiyah. Riyadh: Ammadatu as Su'un al Maktabat Jami'atul Malik Su'udiah.

Kholil, Hilmy. (1997). Muqdodimah Lidirosatil Lughoh. Iskandariyah: Darul Ma'rifah al Jami'iyah.

Kholisi, \& Hanafi, Yusuf. (2005). Fonologi Bahasa Arab. Malang: Program Due-like Bact III, Jur. Sastra Arab Fak. Sastra.

Muhammad Basyar, Kamal. (1980). Ilmu Lughoh al Am. al Qohiroh: Daarul Ma'arif.

Sugiyono. (2003). Pedoman Penelitian Bahasa Lisan: Fonetik. Departemen Pendidikan Nasional: Pusat Bahasa.

Umam, Chotibul. (1980). Aspek-Aspek Fundamental Dalam Mempelajari Bahasa Arab. Bandung: Al Ma'arif.

Verhaar, J.W.M. (2001). Azaz-Azaz Linguistik Umum. Jogyakarta: Gajah Mada University Press. 